\title{
Effects of clove powder supplementation on performance, blood biochemistry, and immune responses in broiler chickens
}

\author{
S.I. Al-Mufarrej, E.H. Fazea, H.H. Al-Baadani\# \& M.M. Qaid \\ Department of Animal Production, College of Food and Agriculture Science, King Saud University, P.O. Box 2460, \\ Riyadh 11451, Kingdom of Saudi Arabia
}

(Received 7 April 2019; Accepted 17 August 2019; First published online 1 October 2019)

Copyright resides with the authors in terms of the Creative Commons Attribution 4.0 South African Licence.
See: http://creativecommons.org/licenses/by/4.0/za
Condition of use: The user may copy, distribute, transmit and adapt the work, but must recognise the authors and the South African
Journal of Animal Science.

\begin{abstract}
The goal of this study was to evaluate the effects of clove (Syzygium aromaticum) supplementation levels on performance, blood parameters, and immune response of broilers. A total of 336 one-day-old broilers were assigned to one of eight treatments: $1 \%$ to $6 \%$ clove supplementation levels, a positive control (vaccinated) and a negative control (unvaccinated). Bodyweight gain, feed intake, feed conversion ratio, serum protein profile, and immune responses were measured weekly. Lymphoid organs were weighed at 21 and 35 days. Levels of dietary clove between $2 \%$ and $6 \%$ supplementation resulted in a gradual decrease in weight gain and feed intake with an increase in feed conversion ratio at two and three weeks, whereas those that received $4 \%$ to $6 \%$ supplementation had reduced weight gain and the $3 \%$ to $6 \%$ supplemented animals consumed the least amount of feed at four and five weeks. High levels of clove supplementation (4\%, $5 \%$, and 6\%) resulted in reduced total serum protein and albumin and the greatest activity of aspartate aminotransferase at 35 days. Antibodies to viruses against which the birds had been vaccinated were not affected by different levels of clove supplementation compared with the positive control. However, they were increased in birds in the negative control group without vaccination. Relative weights of lymphoid organs were not affected by any treatments at 21 and 35 days. These results indicate that clove supplementation at levels greater than $2 \%$ can lead to negative effects on performance without improving the health of the liver and immune responsiveness of broilers.
\end{abstract}

Keywords: Gallus domesticus, serum biochemical, enzymes, antibody titers, lymphoid organs

${ }^{\#}$ Corresponding author: hanee7811@gmail.com

\section{Introduction}

Antibiotics have been used for many years in poultry feed to promote growth and to discourage or eliminate specific pathogenic microorganisms (Gadde et al., 2017). However, the poultry industry is currently moving toward the reduced use of antibiotics because of increased concern about antibiotic-resistant bacteria and antibiotic residue in meat and eggs (Mashayekhi et al., 2018). The European Union (EU) issued a ban on the use of antibiotics in animal feed in 2006 (Belal et al., 2018). However, researchers contend that herbs, medicinal plants and spices may be alternatives to antibiotics for promoting animal health (Vijayasteltar et al., 2016; Al-Shammari et al., 2017). Cloves, cardamom, anise, ginger, black pepper, and cumin are a group of aromatic plants that are used widely due to their positive effects on growth and health of poultry, probably as a result of their immune stimulatory properties (Chowdhury et al., 2018; Kunnumakkara et al., 2018).

Cloves (Syzygium aromaticum) are considered one of the most versatile spices. They contain a large number of biologically active compounds, such as eugenol, eugenol acetate, and $\beta$-caryophyllene (Jimoh et al., 2017). Eugenol is the most biologically active compound in cloves and makes up $70-80 \%$ of clove oil (AlShaikh \& Perveen, 2017). Many studies have evaluated the effects of clove powder (CLP) on performance, immune response, blood parameters, and lymphoid organs in broiler chickens (Mustafa, 2016; Mahrous et al., 2017).

In this study, the authors hypothesized that the use of various levels of CLP might have a differential effect on the performance, blood biochemistry and immune responses in broiler chickens. Therefore, the 
purpose of this study was to evaluate the effects of various levels of CLP on performance, immune responses, blood parameters, and lymphoid organs in broiler chickens.

\section{Materials and Methods}

Clove seeds were purchased from a herbal shop in Riyadh City, Saudi Arabia. It was ground into powder at the College of Food and Agriculture Sciences, King Saud University, Kingdom of Saudi Arabia. The CLP was then added at various levels of concentration in broiler diets. Thus, the CLP used in the study was derived from dry buds of clove.

Three hundred and thirty-six one-day-old mixed-sex broiler chicks (Ross 308) were obtained from a commercial hatchery. Based on similar bodyweight, all chicks were divided randomly into 48 replicates (seven birds per replicate). Feed and water were made freely available to birds during the entire experimental period. The birds were housed in battery-powered electrically heated replicates, with an initial temperature of $35^{\circ} \mathrm{C}$, which was gradually reduced to reach $22^{\circ} \mathrm{C}$ at 21 days old. It was then maintained at this temperature for the remainder of the 35-day period. The corn-soya-based diets were formulated according to the recommendations of the National Research Council (NRC, 1994) and Ross management guide, including a starter ( $23 \%$ crude protein and metabolizable energy $3000 \mathrm{kcal} / \mathrm{kg}$ feed) from 0 to 14 days), and finisher (20\% crude protein and metabolizable energy $3100 \mathrm{kcal} / \mathrm{kg}$ feed) from 15 to 35 days (Table 1). The diets were supplemented with six levels of CLP $(1 \%, 2 \%, 3 \%, 4 \%, 5 \%$, and $6 \%$, based on their basal diet) to form six clove treatment diets along with a positive control (vaccinated birds without CLP) and a negative control (unvaccinated birds without CLP). All treatments and control diets were allocated to six replicates/cages of birds.

Table 1 Composition and calculated nutrient content (\%) of starter and finisher diets for broiler chickens

\begin{tabular}{|c|c|c|}
\hline \multirow{2}{*}{ Ingredients } & \multicolumn{2}{|c|}{ Experimental diet } \\
\hline & Starter (0-14 days) & Finisher (15-35 days) \\
\hline Yellow corn & 57.25 & 58.60 \\
\hline Soybean meal & 30.00 & 30.80 \\
\hline Wheat bran & 0.00 & 2.50 \\
\hline Corn gluten & 6.00 & 0.00 \\
\hline Choline CL 60 & 0.05 & 0.05 \\
\hline Palm oil & 2.19 & 0.00 \\
\hline Fat & 0.00 & 4.40 \\
\hline Dicalcium phosphate & 2.30 & 1.94 \\
\hline Limestone & 0.70 & 0.57 \\
\hline Salt & 0.40 & 0.21 \\
\hline Premix $^{a}$ & 0.50 & 0.50 \\
\hline DL-Methionine & 0.18 & 0.17 \\
\hline Lysine-HCL & 0.32 & 0.14 \\
\hline Threonine & 0.11 & 0.13 \\
\hline \multicolumn{3}{|l|}{ Calculated analysis } \\
\hline Metabolizable energy (Kcal/kg) & 3000 & 3100 \\
\hline Crude protein (\%) & 23 & 20 \\
\hline D-Lysine (\%) & 1.28 & 1.13 \\
\hline Total sulphur amino acids (\%) & 0.95 & 0.86 \\
\hline Calcium (\%) & 0.96 & 0.84 \\
\hline D-Threonine (\%) & 0.86 & 0.74 \\
\hline Non-phytate P (\%) & 0.47 & 0.41 \\
\hline
\end{tabular}

\footnotetext{
${ }^{a}$ vitamin A: $2400000 \mathrm{IU}$; vitamin D: $1000000 \mathrm{IU}$; vitamin E: $16000 \mathrm{IU}$; vitamin K: 800 mg; vitamin B1: 600 mg; vitamin B2: $1600 \mathrm{mg}$; vitamin B6: $1000 \mathrm{mg}$; vitamin B12: $6 \mathrm{mg}$; niacin: $8000 \mathrm{mg}$; folic acid: $400 \mathrm{mg}$; pantothenic acid: 3000 mg; biotin: 40 mg; antioxidant: 3000 mg; cobalt: 80 mg; copper: 2000 mg; iodine: 400; iron: 1200 mg; manganese: $18000 \mathrm{mg}$; selenium: $60 \mathrm{mg}$; zinc: $14000 \mathrm{mg}$
} 
The chickens were vaccinated by nasal instillation against Newcastle disease at 5 and 22 days of age (HB1 and LaSota strains). Similarly, they were vaccinated against infectious bronchitis (H120 strain). They were vaccinated against infectious bursal disease (D78) by nasal instillation at 14 days of age. The vaccinations were based on recommendations of the Ministry of Agriculture in Saudi Arabia.

The weight of chicks and their feed consumption were recorded weekly for each replicate. The average body weight gain (BWG) and feed conversion ratio (FCR) were calculated for each treatment group. The mortality rate was recorded daily.

At $7,14,21,28$, and 35 days, $3 \mathrm{ml}$ blood was collected from the wing vein (brachial vein) from 18 birds per treatment and centrifuged at $3000 \mathrm{rpm}$ for $15 \mathrm{~min}$. Serum was separated and stored at $-80{ }^{\circ} \mathrm{C}$ until analysis was performed. Serum total protein, albumin, alanine aminotransferase (ALT), aspartate aminotransferase (AST), and alkaline phosphatase (ALP) were measured using reagent kits according to the manufacturer's instructions (Randox, Laboratories, Ltd., Crumlin, UK) via a spectrophotometric analyser (UDICHEM 310, United Diagnostics Industry, Dammam, Kingdom of Saudi Arabia). To determine serum globulin, albumin concentration was subtracted from serum total protein according to Albaadani et al. (2018). Enzyme-linked immunosorbent antibody assay (ELISA kits were used according to the manufacturer's instructions (IDEXX, Europe B.V., Hoofddorp, The Netherlands) for lymphoid organ measurements included antibody production against the vaccinated viruses (NDV, IBV, and IBDV).

At 21 and 35 days of age, six birds per treatment were randomly selected based on the average weight of birds subjected to the same treatment and slaughtered. The carcass was dissected to separate the lymphoid organs (thymus, bursa, and spleen) and weighed to calculate the percentage of the thymus, bursa, and spleen to live bodyweight.

The experiment was conducted in a completely randomized design. The following statistical model was used for the experiment:

$$
Y_{i j}=\mu+T_{i}+e_{i j}
$$

Where: $\mu$ is the general mean

$T_{i}$ is the effect of treatment $(i=1, \ldots, 8)$

$e_{i j}$ is the random error associated with $Y_{i j}$ observation

The data were analysed using the general linear model procedure of SAS (SAS Institute Inc., Cary, NC., USA). The statistical differences between means were tested using Tukey's test $(P<0.001)$. All values were expressed as statistical means \pm standard error of the mean (SEM).

\section{Results and Discussion}

Effects of all dietary treatments on performance are presented in Table 2. In the current study, the inclusion of various levels of CLP from $2 \%$ to $6 \%$ resulted in a gradual decrease $(P<0.0001)$ in bodyweight gain (BWG) and daily feed intake (FI) with a gradual increase $(P<0.0001$ and $P=0.015$, respectively) in FCR at two and three weeks old, compared with those of $1 \%$ CLP and the controls (positive and negative). However, the inclusion of CLP at $4 \%$ to $6 \%$ caused a decline in daily weight gain, as well as when $3 \%$ to $6 \%$ of CLP was added to feed intake, compared with other treatments, without any change in FCR in all dietary treatments at 4 and 5 weeks old.

An increased level of cloves, beyond $2 \%$ of the diet, led to a negative effect on performance, which may have been caused by an adverse effect on the palatability of the feed. However, the current results agree with those of Mohammadi et al. (2014), who found that broilers supplemented with clove oil (100 $\mathrm{mg} / \mathrm{kg}, 300 \mathrm{mg} / \mathrm{kg}$, and $500 \mathrm{mg} / \mathrm{kg}$ ) did not grow linearly and had decreased growth performance and total feed intake with the addition $500 \mathrm{mg}$ of cloves $/ \mathrm{kg}$ of diet. Similarly, Agostini et al. (2012) used various levels of clove oil $(100,200,1000$, and $2500 \mathrm{mg} / \mathrm{kg})$, which exhibited decreased growth performance at 1000 and $2500 \mathrm{mg} / \mathrm{kg}$. In another study by Mukhtar (2011), clove oil at 200, 400, and $600 \mathrm{mg} / \mathrm{kg}$ in the diet of birds improved growth performance. In a recent study by Mahrous et al. (2017), no significant differences in growth performance (BWG and FCR) were observed when broiler chickens were fed clove bud supplements at a rate of 0.5 and $1.0 \mathrm{~g} / \mathrm{kg}$ diet, but performance deteriorated in groups supplemented with higher levels of cloves $(1.5 \mathrm{~g} / \mathrm{kg}$ diet). 
Table 2 Effects of clove powder supplementation on performance of broiler chickens

\begin{tabular}{|c|c|c|c|c|c|c|c|c|c|c|}
\hline \multirow{2}{*}{ Days } & \multicolumn{8}{|c|}{ Diet $^{1}$} & \multirow{2}{*}{ SEM $^{2}$} & \multirow{2}{*}{$P$-value } \\
\hline & 1 & 2 & 3 & 4 & 5 & 6 & $\mathrm{C}+$ & C- & & \\
\hline \multicolumn{11}{|c|}{ Bodyweight gain (BWG, g/day) } \\
\hline $1-7$ & $16.79^{\mathrm{ab}}$ & $16.31^{\mathrm{b}}$ & $11.93^{\mathrm{C}}$ & $11.46^{\mathrm{c}}$ & $9.98^{d}$ & $9.50^{d}$ & $17.85^{\mathrm{a}}$ & $16.96^{\mathrm{a}}$ & 0.456 & $<.0001$ \\
\hline $8-14$ & $36.72^{\mathrm{a}}$ & $31.41^{\mathrm{b}}$ & $28.43^{\mathrm{b}}$ & $24.08^{c}$ & $19.69^{d}$ & $16.64^{d}$ & $39.08^{\mathrm{a}}$ & $37.77^{\mathrm{a}}$ & 1.140 & $<.0001$ \\
\hline $15-21$ & $58.58^{\mathrm{a}}$ & $48.83^{b}$ & $42.70^{c}$ & $36.94^{d}$ & $30.46^{\mathrm{e}}$ & $31.59^{\mathrm{e}}$ & $60.37^{a}$ & $61.69^{a}$ & 1.822 & $<.0001$ \\
\hline $22-28$ & $76.47^{\mathrm{bc}}$ & $82.74^{\mathrm{ab}}$ & $80.84^{\mathrm{ab}}$ & $68.98^{\mathrm{C}}$ & $56.90^{d}$ & $55.69^{d}$ & $82.48^{\mathrm{ab}}$ & $91.96^{\mathrm{a}}$ & 4.002 & $<.0001$ \\
\hline 29-35 & $85.07^{a}$ & $88.60^{a}$ & $82.00^{\mathrm{a}}$ & $71.58^{b}$ & $67.77^{\mathrm{b}}$ & $56.47^{c}$ & $88.72^{a}$ & $92.94^{\mathrm{a}}$ & 3.595 & $<.0001$ \\
\hline \multicolumn{11}{|c|}{ Feed intake (FI, g/day) } \\
\hline $1-7$ & $20.8^{\mathrm{b}}$ & $19.5^{\mathrm{c}}$ & $18.6^{\mathrm{cd}}$ & $19.1^{c}$ & $17.4^{\mathrm{d}}$ & $17.4^{\mathrm{d}}$ & $22.0^{\mathrm{a}}$ & $22.2^{\mathrm{a}}$ & 0.415 & $<.0001$ \\
\hline $8-14$ & $47.7^{\mathrm{a}}$ & $42.0^{\mathrm{b}}$ & $39.3^{\mathrm{bc}}$ & $37.7^{c}$ & $32.9^{d}$ & $30.5^{d}$ & $49.9^{\mathrm{a}}$ & $50.7^{a}$ & 1.199 & $<.0001$ \\
\hline $15-21$ & $82.7^{\mathrm{a}}$ & $72.7^{\mathrm{b}}$ & $66.3^{c}$ & $58.1^{d}$ & $48.4^{\mathrm{e}}$ & $46.1^{\mathrm{e}}$ & $84.45^{\mathrm{a}}$ & $86.0^{\mathrm{a}}$ & 1.867 & $<.0001$ \\
\hline $22-28$ & $118.6^{\mathrm{abc}}$ & $117.0^{\mathrm{bc}}$ & $112.3^{\mathrm{c}}$ & $100.8^{d}$ & $86.4^{\mathrm{e}}$ & $80.4^{\mathrm{e}}$ & $127.1^{\mathrm{a}}$ & $123.9^{\mathrm{ab}}$ & 2.823 & $<.0001$ \\
\hline 29-35 & $140.0^{\mathrm{ab}}$ & $146.8^{\mathrm{ab}}$ & $138.6^{b}$ & $122.5^{c}$ & $113.2^{c}$ & $99.6^{d}$ & $153.5^{a}$ & $145.5^{\mathrm{ab}}$ & 4.529 & $<.0001$ \\
\hline \multicolumn{11}{|c|}{ Feed conversion ratio (FCR) } \\
\hline $1-7$ & $1.24^{\mathrm{d}}$ & $1.20^{\mathrm{d}}$ & $1.56^{c}$ & $1.68^{\mathrm{bc}}$ & $1.75^{\mathrm{ab}}$ & $1.84^{\mathrm{a}}$ & $1.24^{d}$ & $1.31^{d}$ & 0.046 & $<.0001$ \\
\hline $8-14$ & $1.30^{d}$ & $1.34^{\mathrm{d}}$ & $1.39^{d}$ & $1.57^{\mathrm{c}}$ & $1.68^{\mathrm{b}}$ & $1.84^{\mathrm{a}}$ & $1.30^{d}$ & $1.33^{d}$ & 0.036 & $<.0001$ \\
\hline $15-21$ & $1.42^{\mathrm{bc}}$ & $1.49^{\mathrm{abc}}$ & $1.57^{\mathrm{ab}}$ & $1.57^{\mathrm{ab}}$ & $1.61^{\mathrm{a}}$ & $1.49^{\mathrm{abc}}$ & $1.42^{\mathrm{bc}}$ & $1.37^{c}$ & 0.050 & 0.0151 \\
\hline $22-28$ & 1.59 & 1.42 & 1.40 & 1.47 & 1.53 & 1.47 & 1.54 & 1.39 & 0.070 & 0.4050 \\
\hline 29-35 & 1.64 & 1.66 & 1.70 & 1.73 & 1.68 & 1.78 & 1.65 & 1.65 & 0.043 & 0.3056 \\
\hline
\end{tabular}

${ }^{1} 1$ to 6 indicates the percentage of clove powder in the diet, C+ indicates the positive control group (vaccinated and not receiving clove powder) and C- indicates the negative control group (unvaccinated and also not receiving clove powder) ${ }^{2}$ SEM: standard error of means for treatment effect

${ }^{a-e}$ Values within rows with different superscripts are significantly different $(P<0.05)$

Effects of dietary CLP on total protein, albumin, and globulin in serum of the broilers are shown in Table 3. Concentrations of serum total protein in all treatments were similar at 7 and 14 days old. However, the concentration of serum total protein was significantly reduced at day $21(P=0.04)$ in groups that received high levels of CLP at $5 \%$ and $6 \%$ of diet, compared with birds in groups that received $1 \%, 2 \%$, and $3 \%$ of CLP. Serum total protein concentration decreased significantly $(P=0.03)$ in comparison with groups that received 1\% CLP against the same treatment groups (5\% and $6 \%$ CLP/kg of diet) at day 28 . In addition, serum total protein concentration decreased significantly $(P=0.02)$ in treatment groups that received high levels of $\operatorname{CLP}(4,5$, and $6 \%$ of diet) compared with birds in treatment groups that received $3 \%$ of CLP in the diet at day 35. However, birds in all treatment groups did not differ significantly compared with the control groups (positive and negative control). Birds that received $5 \%$ and $6 \%$ of CLP showed reduced albumin levels compared with the positive control. However, birds that received lower levels of supplementation had similar levels of serum albumin and did not differ from either control at 35 days of age. Albumin levels in all treatments were not influenced at younger ages $(7,14,21$, and 28 days of age). Levels of globulin were not affected by treatments at any age $(P>0.10)$. These results agree with those of other investigators, who reported that total serum protein, albumin, and globulin levels of birds were not affected by $0.5 \%$ CLP compared with those of the control group (Tariq et al., 2014). Furthermore, Chowdhury et al. (2018) used dietary clove bud oil at $0.6 \%$ and did not report a significant influence on serum total protein in broiler chickens.

Many medicinal herbs and plants have similar effects on the blood biochemical profile in poultry. For example, Hassan and Awad (2017) stated that $0.2 \%, 0.5 \%$, and $0.8 \%$ dietary supplementation with thyme powder in broilers did not affect serum total protein, albumin, and globulin when compared with that of the control group. Saeid et al. (2010) reported that $0.4 \%$ and $0.6 \%$ of ginger had no significant effect on serum total protein, albumin, and globulin compared with that of the control group in broilers. However, Natsir et al. (2017) showed that a mix of garlic and Phyllanthus niruri at 1.2\% of the broiler diets had no significant effects on serum globulin, whereas significant differences were observed in serum total protein and albumin 
compared with the control group. Furthermore, Jafari et al. (2011) reported that dietary garlic powder supplementation at the levels of $1 \%$ and $3 \%$ had no effects on serum globulin in broiler chicks, but it tended to decline with age.

Table 3 Effects of clove powder supplementation on serum total protein, albumin, and globulin in broiler chickens

\begin{tabular}{|c|c|c|c|c|c|c|c|c|c|c|}
\hline \multirow{2}{*}{ Days } & \multicolumn{8}{|c|}{ Diet $^{1}$} & \multirow{2}{*}{ SEM $^{2}$} & \multirow{2}{*}{$P$-value } \\
\hline & 1 & 2 & 3 & 4 & 5 & 6 & $\mathrm{C}+$ & C- & & \\
\hline \multicolumn{11}{|c|}{ Total protein (g/dl) } \\
\hline 7 & 3.29 & 3.37 & 3.21 & 3.33 & 3.14 & 3.14 & 3.21 & 3.17 & 0.07 & 0.32 \\
\hline 14 & 3.10 & 3.28 & 3.36 & 3.37 & 3.29 & 3.43 & 3.36 & 3.39 & 0.08 & 0.44 \\
\hline 21 & $3.29^{\mathrm{a}}$ & $3.35^{a}$ & $3.37^{a}$ & $3.24^{\mathrm{ab}}$ & $3.01^{b}$ & $3.00^{\mathrm{b}}$ & $3.10^{\mathrm{ab}}$ & $3.16^{\mathrm{ab}}$ & 0.08 & 0.04 \\
\hline 28 & $3.55^{\mathrm{a}}$ & $3.49^{\mathrm{ab}}$ & $3.45^{\mathrm{ab}}$ & $3.42^{\mathrm{ab}}$ & $3.31^{\mathrm{b}}$ & $3.34^{\mathrm{b}}$ & $3.45^{\mathrm{ab}}$ & $3.44^{\mathrm{ab}}$ & 0.06 & 0.03 \\
\hline 35 & $3.32^{\mathrm{ab}}$ & $3.27^{\mathrm{ab}}$ & $3.51^{a}$ & $3.11^{b}$ & $3.12^{b}$ & $3.06^{b}$ & $3.23^{\mathrm{ab}}$ & $3.20^{\mathrm{ab}}$ & 0.07 & 0.02 \\
\hline \multicolumn{11}{|c|}{ Albumin (g/dl) } \\
\hline 7 & 1.89 & 1.95 & 1.90 & 1.91 & 1.80 & 1.81 & 1.94 & 1.83 & 0.05 & 0.39 \\
\hline 14 & 1.77 & 1.76 & 1.68 & 1.88 & 1.88 & 1.76 & 1.86 & 1.74 & 0.05 & 0.11 \\
\hline 21 & 1.95 & 1.93 & 1.92 & 1.85 & 1.88 & 1.91 & 1.90 & 1.88 & 0.04 & 0.54 \\
\hline 28 & 2.12 & 2.19 & 1.99 & 1.92 & 1.98 & 1.89 & 2.00 & 2.07 & 0.06 & 0.06 \\
\hline 35 & $1.89^{\mathrm{ab}}$ & $1.87^{\mathrm{ab}}$ & $1.83^{\mathrm{ab}}$ & $1.88^{\mathrm{ab}}$ & $1.78^{b}$ & $1.77^{\mathrm{b}}$ & $2.01^{a}$ & $1.95^{\mathrm{ab}}$ & 0.04 & 0.02 \\
\hline \multicolumn{11}{|c|}{ Globulin (g/dl) } \\
\hline 7 & 1.37 & 1.39 & 1.72 & 1.56 & 1.24 & 1.27 & 1.39 & 1.37 & 0.13 & 0.42 \\
\hline 14 & 1.46 & 1.33 & 1.89 & 1.51 & 1.58 & 1.49 & 1.44 & 1.73 & 0.17 & 0.37 \\
\hline 21 & 1.35 & 1.41 & 1.41 & 1.36 & 1.01 & 1.11 & 1.40 & 1.24 & 0.14 & 0.31 \\
\hline 28 & 1.44 & 1.42 & 1.53 & 1.53 & 1.47 & 1.37 & 1.52 & 1.32 & 0.10 & 0.43 \\
\hline 35 & 1.27 & 1.45 & 1.42 & 1.49 & 1.12 & 1.23 & 1.18 & 1.43 & 0.15 & 0.13 \\
\hline
\end{tabular}

${ }^{1} 1$ to 6 indicates the percentage of clove powder in the diet, $\mathrm{C}+$ indicates the positive control group (vaccinated and not receiving clove powder) and $\mathrm{C}$ - indicates the negative control group (unvaccinated and also not receiving clove powder) ${ }^{2}$ SEM: standard error of means for treatment effect

${ }^{\mathrm{a}-\mathrm{b}}$ Values within rows with different superscripts are significantly different $(P<0.05)$

Liver enzyme activity levels were not affected $(P>0.05)$ by treatments at all times of collection $(7,14$, 21,28 , and 35 days old), except that AST activity was greatest in birds that received high levels of cloves at $5 \%$ and $6 \%$ compared with all other treatments at 35 days old (Table 4). The AST enzyme is one of the biomarkers of liver functions. Thus, the high AST levels observed in treatment groups that received $5 \%$ and $6 \%$ levels of CLP per $\mathrm{kg}$ of diet may be an indication that CLP at those concentrations can adversely affect liver function, and damage often results in abnormally heightened levels of liver enzymes (Kaplan et al., 2003). There were no studies on the effects of inclusion of high levels of CLP in broiler chicken diets on serum biochemical parameters, including total protein, albumin, globulin, AST, ALT, and ALP. Many researchers have studied lower dietary levels of CLP compared with the current study. For example, Mahrous et al. (2017) used concentrations of CLP at 0.5, 1.0, and $1.5 \mathrm{~g} / \mathrm{kg}$ in the diet of broiler chickens and found that ALT activity was not significantly affected at the third and fifth weeks. Mustafa (2016) showed no significant differences in AST, ALT, and ALP enzyme concentrations when broiler chickens were fed mixed essential oils (clove, anise, and caraway) at a rate of 200,400 , and $600 \mathrm{mg} / \mathrm{kg}$ feed. However, the ALP enzyme proportion was slightly decreased at $600 \mathrm{mg} / \mathrm{kg}$.

In other species, dietary supplementation with cloves has had mixed effects. Hoseini et al. (2011) used 300, 500, and $700 \mathrm{mg} / \mathrm{L}$ of CLP and observed no effect on serum levels of AST, ALT, and ALP in beluga sturgeon (Huso huso). Moreover, Vijayasteltar et al. (2016) reported that CLP inclusion at 0.25, 0.50, and $1.0 \mathrm{~g} / \mathrm{kg}$ in the diet of rats did not affect AST, ALT, and ALP activity. In another study, Velisek et al. (2005) used clove oil at 0.3, 0.5, 0.7, 0.9, and $1.1 \mathrm{~g} / \mathrm{L}$ and reported unchanged AST, ALT, and ALP in carp. 
Kazi et al. (2017) also used CLP at $1 \mathrm{~g} / \mathrm{kg}$ and observed no effects on AST, ALT, and ALP activity in rabbits. Moreover, the actions of AST and ALT showed no significant differences for all treatments in rats fed clove extract at 250 and $500 \mathrm{mg} / \mathrm{kg}$ diet (Saeed et al., 2017). In another study, Mustafa (2016) showed no significant differences in AST, ALT, and ALP enzyme concentrations in broiler chickens fed mixed essential oils (cloves, anise, and caraway) at a rate of 200,400 , and $600 \mathrm{mg} / \mathrm{kg}$ feed. However, ALP activity was slightly decreased in broiler chickens fed $600 \mathrm{mg} / \mathrm{kg}$ feed compared with that of the other groups. An experiment conducted on the fish Labeo rohita by Asimi \& Sahu (2016) indicated that the concentrations of ALT, AST, and ALP enzymes in liver and muscle were decreased in groups fed 0.5 and $1.0 \%$ clove extract compared with that of the control group. Furthermore, Gashlan \& Al-Beladi (2017) observed a decrease in liver AST, AST, and ALP in rats fed clove oil at 300 and $600 \mathrm{mg} / \mathrm{kg}$ feed compared with the control group.

Table 4 Effects of clove powder supplementation on liver enzymes of broiler chickens

\begin{tabular}{|c|c|c|c|c|c|c|c|c|c|c|}
\hline \multirow{2}{*}{ Days } & \multicolumn{8}{|c|}{ Diet $^{1}$} & \multirow{2}{*}{ SEM $^{2}$} & \multirow{2}{*}{$P$-value } \\
\hline & 1 & 2 & 3 & 4 & 5 & 6 & $\mathrm{C}+$ & C- & & \\
\hline
\end{tabular}

\section{ALT (IU/L)}

\begin{tabular}{|c|c|c|c|c|c|c|c|c|c|c|}
\hline 7 & 8.09 & 6.64 & 7.74 & 7.86 & 7.86 & 8.00 & 7.94 & 7.61 & 1.16 & 0.97 \\
\hline 14 & 7.92 & 6.94 & 9.01 & 9.09 & 9.42 & 10.44 & 9.57 & 9.30 & 0.99 & 0.32 \\
\hline 21 & 8.36 & 7.88 & 9.82 & 9.50 & 10.36 & 10.38 & 9.19 & 9.76 & 0.97 & 0.60 \\
\hline 28 & 9.17 & 8.45 & 9.44 & 9.77 & 10.92 & 11.08 & 10.34 & 10.06 & 0.69 & 0.08 \\
\hline 35 & 8.06 & 8.01 & 8.72 & 10.49 & 11.07 & 11.10 & 10.06 & 10.34 & 0.98 & 0.18 \\
\hline \multicolumn{11}{|c|}{ AST (IU/L) } \\
\hline 7 & 128.1 & 131.7 & 130.6 & 133.9 & 137.7 & 139.7 & 133.5 & 127.3 & 6.05 & 0.55 \\
\hline 14 & 134.3 & 133.6 & 150.1 & 150.9 & 157.8 & 160.2 & 148.7 & 130.0 & 7.07 & 0.06 \\
\hline 21 & 126.1 & 130.4 & 140.4 & 139.4 & 145.6 & 148.1 & 131.3 & 142.3 & 5.70 & 0.24 \\
\hline 28 & 133.5 & 145.6 & 145.6 & 145.6 & 150.0 & 156.9 & 134.2 & 130.7 & 6.43 & 0.20 \\
\hline 35 & $160.4^{b}$ & $170.3^{b}$ & $180.6^{\mathrm{ab}}$ & $181.2^{\mathrm{ab}}$ & $194.4^{\mathrm{a}}$ & $193.3^{\mathrm{a}}$ & $166.8^{b}$ & $166.2^{b}$ & 6.62 & 0.01 \\
\hline \multicolumn{11}{|c|}{ ALP (U/L) } \\
\hline 7 & 1374 & 1420 & 1464 & 1452 & 1480 & 1490 & 1416 & 1400 & 60.15 & 0.91 \\
\hline 14 & 1400 & 1364 & 1336 & 1412 & 1471 & 1473 & 1345 & 1395 & 63.60 & 0.85 \\
\hline 21 & 1291 & 1285 & 1366 & 1340 & 1398 & 1396 & 1338 & 1390 & 75.95 & 0.95 \\
\hline 28 & 1190 & 1196 & 1248 & 1315 & 1309 & 1330 & 1238 & 1236 & 57.48 & 0.59 \\
\hline 35 & 995 & 1082 & 1124 & 1159 & 1223 & 1232 & 992 & 1017 & 59.01 & 0.09 \\
\hline
\end{tabular}

Antibody titers against NDV vaccine at 28 days were significantly $(P<0.05)$ greater in $1 \%, 2 \%$, and $3 \%$ CLP groups compared with both the positive and negative controls (Table 5). However, at 14 and 35 days old, greater $(P<0.05)$ antibody titers were observed among the vaccinated birds compared with the unvaccinated birds (negative control). Nonetheless, the various levels of CLP did not show significant effects on the titers of antibodies that are specific to NDV compared with the positive control in the first and third weeks old (Table 5).

Antibody titers against the IBV vaccine at 28 and 35 days showed a significant $(P<0.05)$ difference between the vaccinated birds and the unvaccinated birds, whereas the negative control had a lower antibody titer compared with that of other treatments. However, no significant $(P>0.05)$ differences were observed between the broilers that fed on CLP and the positive control group (Table 5). 
Table 5 Effects of clove powder supplementation on specific antibody titers of broiler chickens

\begin{tabular}{|c|c|c|c|c|c|c|c|c|c|c|}
\hline \multirow{2}{*}{ Days } & \multicolumn{8}{|c|}{ Diet $^{1}$} & \multirow{2}{*}{ SEM $^{2}$} & \multirow{2}{*}{$P$-value } \\
\hline & 1 & 2 & 3 & 4 & 5 & 6 & $\mathrm{C}+$ & C- & & \\
\hline \multicolumn{11}{|c|}{ Newcastle disease virus } \\
\hline 7 & 3.97 & 3.96 & 3.99 & 3.89 & 3.85 & 3.95 & 3.93 & 3.80 & 0.09 & 0.24 \\
\hline 14 & $3.59^{\mathrm{a}}$ & $3.53^{\mathrm{a}}$ & $3.49^{\mathrm{a}}$ & $3.43^{\mathrm{a}}$ & $3.33^{\mathrm{a}}$ & $3.46^{\mathrm{a}}$ & $3.43^{\mathrm{a}}$ & $3.00^{b}$ & 0.11 & 0.001 \\
\hline 21 & 2.57 & 2.68 & 2.55 & 2.55 & 2.48 & 2.30 & 2.50 & 2.18 & 0.11 & 0.08 \\
\hline 28 & $2.12^{\mathrm{a}}$ & $1.11^{\mathrm{a}}$ & $2.12^{\mathrm{a}}$ & $2.01^{\mathrm{ab}}$ & $1.82^{\mathrm{b}}$ & $2.78^{b}$ & $1.76^{\mathrm{b}}$ & $1.13^{\mathrm{c}}$ & 0.10 & $<.0001$ \\
\hline 35 & $3.62^{a}$ & $3.60^{a}$ & $3.62^{\mathrm{a}}$ & $3.57^{\mathrm{a}}$ & $3.57^{\mathrm{a}}$ & $3.41^{a}$ & $3.28^{\mathrm{a}}$ & $1.00^{\mathrm{b}}$ & 0.12 & $<.0001$ \\
\hline \multicolumn{11}{|c|}{ Infectious bronchitis disease virus } \\
\hline 7 & 2.86 & 2.85 & 2.89 & 2.90 & 2.87 & 2.78 & 2.89 & 2.50 & 0.11 & 0.07 \\
\hline 14 & 2.36 & 2.29 & 2.17 & 2.27 & 2.11 & 2.19 & 2.22 & 2.15 & 0.09 & 0.18 \\
\hline 21 & 1.74 & 1.74 & 1.76 & 1.66 & 1.67 & 1.55 & 1.66 & 1.33 & 0.07 & 0.49 \\
\hline 28 & $2.06^{\mathrm{a}}$ & $2.00^{\mathrm{a}}$ & $1.99^{\mathrm{a}}$ & $2.03^{a}$ & $2.01^{\mathrm{a}}$ & $1.91^{\mathrm{a}}$ & $1.98^{\mathrm{a}}$ & $1.06^{\mathrm{b}}$ & 0.06 & $<.0001$ \\
\hline 35 & $2.33^{\mathrm{a}}$ & $2.40^{\mathrm{a}}$ & $2.28^{\mathrm{a}}$ & $2.31^{\mathrm{a}}$ & $2.20^{\mathrm{a}}$ & $2.28^{\mathrm{a}}$ & $2.27^{\mathrm{a}}$ & $0.96^{b}$ & 0.10 & $<.0001$ \\
\hline \multicolumn{11}{|c|}{ Infectious bursal disease virus } \\
\hline 7 & 3.17 & 3.20 & 3.12 & 3.13 & 3.14 & 3.12 & 3.11 & 3.11 & 0.10 & 0.89 \\
\hline 14 & 2.49 & 2.54 & 2.28 & 2.14 & 2.27 & 2.30 & 2.30 & 2.27 & 0.09 & 0.07 \\
\hline 21 & 1.85 & 1.77 & 1.70 & 1.76 & 1.69 & 1.69 & 1.67 & 1.61 & 0.11 & 0.67 \\
\hline 28 & $2.02^{a}$ & $1.98^{\mathrm{ab}}$ & $1.91^{\mathrm{abc}}$ & $1.95^{\mathrm{ab}}$ & $1.88^{\mathrm{abc}}$ & $1.86^{\mathrm{bc}}$ & $1.77^{\mathrm{c}}$ & $1.31^{d}$ & 0.05 & $<.0001$ \\
\hline 35 & $2.22^{\mathrm{a}}$ & $2.21^{\mathrm{ab}}$ & $2.19^{\mathrm{ab}}$ & $2.02^{\mathrm{ab}}$ & $2.23^{\mathrm{a}}$ & $2.11^{\mathrm{ab}}$ & $1.99^{b}$ & $1.12^{\mathrm{c}}$ & 0.07 & $<.0001$ \\
\hline
\end{tabular}

${ }^{1} 1$ to 6 indicates the percentage of clove powder in the diet, C+ indicates the positive control group (vaccinated and not receiving clove powder) and $\mathrm{C}$ - indicates the negative control group (unvaccinated and also not receiving clove powder) ${ }^{2}$ SEM: standard error of means for treatment effect

${ }^{\mathrm{a}-\mathrm{b}}$ Values within rows with different superscripts are significantly different $(P<0.05)$

The antibody titers against IBDV were significantly $(P<0.05)$ increased at day 28 in treatments with $1 \%, 2 \%$, and $4 \%$ CLP compared with the positive control group. There was also a significantly $(P<0.05)$ increased antibody titer against IBDV in the $3 \%, 5 \%$, and $6 \%$ CLP, and positive control groups compared with that of the negative control (Table 5).

These results agree with those of other investigators, such as Chowdhury et al. (2018), who noted that dietary inclusion of clove bud oil at $0.6 \%$ increased the antibody titers against NDV in broiler chickens at the age of 28 and 35 days. Furthermore, Gandomani et al. (2014) found that antibody titers against NDV and IBDV were improved in laying hens fed diets supplemented with 0.2 and $0.4 \%$ CLP compared with those of the control group. In addition, Mehr et al. (2014) showed that dietary clove oil at $0.45 \mathrm{~g} / \mathrm{kg}$ significantly increased immunoglobulin $M$ and T cells. Similarly, Bello et al. (2016) reported that clove is a potent immunomodulatory agent that can improve B cell functions, humoral responses, and immunoglobulin (IgA, IgG, IgM) levels. Furthermore, Mahrous et al. (2017) found that the levels of serum immunoglobulin (IgA, IgG, and IgM) were significantly $(P<0.05)$ increased in broiler chickens fed diets supplemented with $1.0 \%$ and $1.5 \%$ CLP. On the other hand, the exact mechanism by which clove and other phytogenic feed additives stimulate the immune responses in chickens and other animals is mostly unknown (Nimmerjahn \& Ravetch, 2010). It is possible that clove and other herbs act as additional bonds with immunoglobulin molecules at the Fc receptors, which stimulate the immune response (Ahmed et al., 2013). In contrast to the results of this study, Najafi \& Torki (2010) noted that antibodies against NDV did not differ significantly in broiler chickens fed a diet supplemented with $200 \mathrm{mg} / \mathrm{kg}$ of clove oil for 42 days. Also, Mehr et al. (2014) found that dietary inclusion of clove oil at $0.15,0.30 \mathrm{~g} / \mathrm{kg}$ did not affect antibody titers against NDV and avian influenza in broiler chickens. Moreover, Poorghasemi et al. (2017) reported that antibody titers against NDV and IBDV were not affected by dietary lemon balm supplementation in broiler chickens. Additionally, Toghyani et al. (2011) stated that antibody titers against avian influenza virus and NDV were not significantly different in broiler chickens fed diets supplemented with $2 \mathrm{~g} / \mathrm{kg}$ and $4 \mathrm{~g} / \mathrm{kg}$ of cinnamon bark powder. Similarly, Soltan et 
al. (2008) showed that the antibody titer against NDV was not significantly different in broiler chickens fed diets supplemented with anise seed compared with that of the control group.

Relative weights of lymphoid organs are presented in Table 6. There were no significant treatment effects on the relative weights of bursa, spleen, and thymus at 21 and 35 days old. These results agree with those of Chowdhury et al. (2018), who observed that CLP supplementation at $0.6 \%$ concentration did not affect the relative weights of the lymphoid organs. In contrast, Gandomani et al. (2014) found that a rise in clove bud powder content resulted in increased relative weight of the spleen of laying hens. This inconsistency may be attributed to the differences in the sources of the clove plants, the levels of CLP, and diet composition or environmental conditions.

Table 6 Effects of clove powder supplementation on the relative weight of lymphoid organs of broiler chickens

\begin{tabular}{|c|c|c|c|c|c|c|c|c|c|c|}
\hline \multirow{2}{*}{ Organ weight } & \multicolumn{8}{|c|}{ Diet $^{1}$} & \multirow{2}{*}{$\mathrm{SEM}^{2}$} & \multirow{2}{*}{$P$-value } \\
\hline & 1 & 2 & 3 & 4 & 5 & 6 & $\mathrm{C}+$ & C- & & \\
\hline \multicolumn{11}{|c|}{ At 21 days of age } \\
\hline Thymus\% & 0.41 & 0.41 & 0.41 & 0.39 & 0.40 & 0.40 & 0.41 & 0.37 & 0.019 & 0.810 \\
\hline Bursa\% & 0.23 & 0.21 & 0.23 & 0.20 & 0.20 & 0.19 & 0.19 & 0.19 & 0.018 & 0.582 \\
\hline Spleen\% & 0.09 & 0.09 & 0.09 & 0.09 & 0.09 & 0.08 & 0.08 & 0.08 & 0.004 & 0.571 \\
\hline \multicolumn{11}{|c|}{ At 35 days of age } \\
\hline Thymus\% & 0.40 & 0.44 & 0.43 & 0.44 & 0.43 & 0.43 & 0.39 & 0.36 & 0.025 & 0.282 \\
\hline Bursa\% & 0.19 & 0.16 & 0.18 & 0.17 & 0.16 & 0.15 & 0.17 & 0.16 & 0.016 & 0.650 \\
\hline Spleen\% & 0.10 & 0.09 & 0.09 & 0.10 & 0.10 & 0.10 & 0.09 & 0.09 & 0.006 & 0.325 \\
\hline
\end{tabular}

${ }^{1} 1$ to 6 indicates the percentage of clove powder in the diet, C+ indicates the positive control group (vaccinated and not receiving clove powder) and $\mathrm{C}$ - indicates the negative control group (unvaccinated and also not receiving clove powder)

${ }^{2}$ SEM: standard error of means for treatment effect

\section{Conclusion}

An increased level of cloves (greater than 2\%) had a negative effect on performance of broiler chickens, which may be attributed to an adverse effect on the palatability of the feed without affecting the health of the liver and immune responsiveness. Further research is essential to clarify the mechanism behind this effect.

\section{Acknowledgments}

The authors would like to thank Deanship of scientific research for funding and supporting this research through the initiative of DSR Graduate Students Research Support (GSR). The authors also would like to extend their sincere appreciation to RSSU at King Saud University for their technical support.

\section{Authors' Contribution}

SI supervised the study. SI and EH conceived and designed it. EH conducted the experiment and analysed the samples and the data. $\mathrm{EH}, \mathrm{MM}$, and $\mathrm{HH}$ contributed in writing and revised the manuscript. All authors interpreted the data, critically revised the manuscript for important intellectual contents and approved the final version.

\section{Conflict of Interest Declaration}

There is no conflict of interest.

\section{References}

Agostini, P.S., Solà-Oriol, D., Nofrarías, M., Barroeta, A.C., Gasa, J. \& Manzanilla, E.G., 2012. Role of in-feed clove supplementation on growth performance, intestinal microbiology, and morphology in broiler chicken. Livest. Sci. $147,113-118$.

Ahmed, S.T., Hossain, M.E., Kim, G.M., Hwang, J.A., Ji, H. \& Yang, C.J., 2013. Effects of resveratrol and essential oils on growth performance immunity, digestibility and fecal microbial shedding in challenged piglets. Asian-Australas. J. Anim. Sci. 26, 683-690. 
Al-Baadani, H.H., Abudabos, A.M., Al-Mufarrej, S.I., Al-Baadani, A.A. \& Alhidary, I.A., 2018. Dietary supplementation of Bacillus subtilis, Saccharomyces cerevisiae and their symbiotic effect on serum biochemical parameters in broilers challenged with Clostridium perfringens. J. Appl. Anim. Res. 46, 1064-1072.

Al-Shaikh, N. \& Perveen, K., 2017. Anti-candidal activity and chemical composition of essential oil of clove (Syzygium aromaticum). J. Essent. Oil Bear. PI. 20, 951-958.

Al-Shammari, K.I., Batkowska, J. \& Gryzińska, M.M., 2017. Effect of various concentrations of an anise seed powder (Pimpinella Anisum L.) supplement on selected hematological and biochemical parameters of broiler chickens. Braz. J. Poult. Sci. 19, 41-46.

Asimi, O.A. \& Sahu, N.P., 2016. Effect of antioxidant-rich spices, clove and cardamom extracts on the metabolic enzyme activity of Labeo rohita. J. Fisheries Livest. Prod. 4, 1-6.

Belal, S.A., Uddin, M.N., Hasan, M.K., Islam, M.S. \& Islam, M.A., 2018. Effect of ginger (Zingiber officinale) and garlic (Allium sativum) on productive performance and hematological parameters of the broiler. Int. J. Environ. Res. 4, $12-23$.

Bello, A.U., Sulaiman, J.A. \& Aliyu, M.S., 2016. Acute phase protein mRNA expressions and enhancement of antioxidant defense system in black-meated silkie fowls supplemented with clove (Eugenia caryophyllus) extracts under the influence of chronic heat stress. J. Anim. Sci. Tech. 58, 39.

Chowdhury, S., Mandal, G.P., Patra, A.K., Kumar, P., Samanta, I., Pradhan, S. \& Samanta, A.K., 2018. Different essential oils in diets of broiler chickens: 2. Gut microbes and morphology, immune response, and some blood profile and antioxidant enzymes. Anim. Feed Sci. Tech. 236, 39-47.

Gadde, U., Kim, W.H., Oh, S.T. \& Lillehoj, H.S., 2017. Alternatives to antibiotics for maximizing growth performance and feed efficiency in poultry: A review. Anim. Health Res. Rev. 18, 26-45.

Gandomani, V.T., Mahdavi, A.H., Rahmani, H.R., Riasi, A. \& Jahanian, E., 2014. Effects of different levels of clove bud (Syzygium aromaticum) on performance, intestinal microbial colonization, jejunal morphology, and immunocompetence of laying hens fed different n-6 to n-3 ratios. Livest. Sci. 167, 236-248.

Gashlan, H.M. \& Al-Beladi, A.B., 2017. Effects of clove oil on liver and antioxidant status of streptozotocin-induced diabetic rats. G.A.R.J.M.M.S. 6, 103-110.

Hassan, F.A. \& Awad, A., 2017. Impact of thyme powder (Thymus vulgaris L.) supplementation on gene expression profiles of cytokines and economic efficiency of broiler diets. Environ Sci. Pollut. Res. 24, 15816-15826.

Hoseini, S.M., Hosseini, S.A. \& Nodeh, A.J., 2011. Serum biochemical characteristics of Beluga, huso (L.), in response to blood sampling after clove powder solution exposure. Fish Physiol. Biochem. 37, 567-572.

Jafari, R.A., Razi-Jalali, M. \& Kiani, R., 2011. Effect of fresh dietary garlic powder on some of the serum biochemical parameters in broiler chicks. Comp. Clin. Pathol. 20, 295-297.

Jimoh, S.O., Arowolo, L.A. \& Alabi, K.A., 2017. Phytochemical screening and antimicrobial evaluation of Syzygium aromaticum extract and essential oil. I.J.C.M.A.S. 6, 4557-4567.

Kaplan, L., Pesce, A. \& Kazmierczak, S., 2003. Liver function. In: Sherwin, J.E. (ed.) Clinical chemistry: theory, analysis, correlation, 4th ed. Mosby Inc. Ed., St. Louis, MO, USA.

Kazi, S., Ansari, M.A., Memon, A.R., Memon, A.R. \& Phull, Q.Z., 2017. Reversal of paracetamol induced hepatotoxicity in animals model: Clove, an alternative medicine beyond the spices. J.L.U.M.H.S. 16, 154-157.

Kunnumakkara, A.B., Sailo, B.L., Banik, K., Harsha, C., Prasad, S., Gupta, S.C. \& Aggarwal, B.B., 2018. Chronic diseases, inflammation, and spices: How are they linked. J. Transl. Med. 16, 1-14.

Mahrous, H.S., El-Far, A.H., Sadek, K.M. \& Abdel-Latif, M.A., 2017. Effects of different levels of clove bud (Syzygium aromaticum) dietary supplementation on immunity, antioxidant status, and performance in broiler chickens. A.J.V.S. 54, 29-39.

Mashayekhi, H., Mazhari, M. \& Esmaeilipour, O., 2018. Eucalyptus leaves powder, antibiotic and probiotic addition to broiler diets: Effect on growth performance, immune response, blood components and carcass traits. Animal 12, 2049-2055.

Mehr, M.A., Hassanabadi, A., Moghaddam, H.N. \& Kermanshahi, H., 2014. Supplementation of clove essential oils and probiotic on blood components, lymphoid organs and immune response in broiler chickens. Res. Opin. Anim. Vet. Sci. 4, 218-223.

Mohammadi, Z., Ghazanfari, S. \& Moradi, M.A., 2014. Effect of supplementing clove essential oil to the diet on microflora population, intestinal morphology, blood parameters and performance of broilers. Eur. Poult. Sci. 78, 1-11.

Mukhtar, M.A., 2011. The effect of dietary clove oil on broiler performance. Aust. J. Basic Appl. Sci. 5, 49-51.

Mustafa, D.B.M., 2016. Effect of mixture of three herbal essential oils on performance, carcass yield and blood serum constituents of broiler chicks. Sudan Univer. Sci. Tech. 5, 63-72.

Najafi, P. \& Torki, M., 2010. Performance, blood metabolites and immunocompetence of broiler chicks fed diets included essential oils of medicinal herbs. J. Anim. Vet. Adv. 9, 1164-1168.

Natsir, M.H., Hartutik, Sjofjan, O., Widodo, E. \& Widyastuti, E.S., 2017. Use of acidifiers and herb-acidifier combinations with encapsulated and non-encapsulated intestinal microflora, intestinal histological and serum characteristics in broiler. A.I.P. Conf. Proc. 1844, 20012-20019.

Nimmerjahn, F. \& Ravetch, J.V., 2010. Antibody-mediated modulation of immune responses. Immunol. Rev. 236, 265275.

NRC, 1994. Nutrient requirements of poultry. National Academies Press, Washington, DC.

Poorghasemi, M., Seidavi, A., Mohammadi, M., Simões, J., Laudadio, V. \& Tufarelli, V., 2017. Effect of dietary inclusion of lemon balm (melissa officinalis I.) extract on performance, gut microflora, blood parameters, immunity and carcass traits of broilers. Poult. Sci. 10, 21-41. 
Saeed, T.A., Osman, O.A., Amin, A.E. \& El-Badwi, S.M., 2017. Safety assessment and potential anti-inflammatory effect of ethanolic extract of Syzygium aromaticum in albino rats. Adv. Biosci. Biotechnol. 8, 411-420.

Saeid, J.M., Mohamed, A.B. \& AL-Baddy, M.A., 2010. Effect of aqueous extract of ginger (Zingiber officinale) on blood biochemistry parameters of broiler. Intern. J. Poult. Sci. 9, 944-947.

Soltan, M.A., Shewita, R.S. \& El-Katcha, M.I., 2008. Effect of dietary anise seeds supplementation on growth performance, immune response, carcass traits and some blood parameters of broiler chickens. Intern. J. Poult. Sci. 7, 1078-1088.

Tariq, H., Rao, P.V., Mondal, B.C. \& Malla, B.A., 2014. Effect of Aloe vera (Aloe barbadensis) and clove (Syzygium aromaticum) supplementation on immune status, haematological and serum biochemical parameters in Japanese quails. Indian J. Anim. Nutrit. 31, 293-296.

Toghyani, M., Toghyani, M., Gheisari, A.A., Ghalamkari, G. \& Eghbalsaeid, S., 2011. Evaluation of cinnamon and garlic as antibiotic growth promoter substitutions on performance, immune responses, serum biochemical and haematological parameters in broiler chicks. Livest. Sci. 138, 167-173.

Velisek, J., Svobodova, Z., Piackova, V., Groch, L. \& Nepejchalova, L., 2005. Effects of clove oil anaesthesia on common carp (Cyprinus carpio L.). Vet. Med. 50, 269-275.

Vijayasteltar, L., Nair, G.G., Maliakel, B., Kuttan, R. \& Krishnakumar, I.M., 2016. Safety assessment of a standardized polyphenolic extract of clove buds: Subchronic toxicity and mutagenicity studies. Toxicol. Repor. 3, 439-449. 